\title{
Letter to an Imaginary Soviet Scientist
}

The problems of cultural relations between countries which speak different languages are necessarily formidable, but the following letter suggests that these problems may sometimes be needlessly complicated.

Dear colleague,

The news of your election to the Soviet Academy has just reached us here, and I hasten to add my congratulations to those of your other friends and admirers. It does not seem fifteen years since we began to notice your name as the author of a series of brilliant contributions to our subject, and wondered whether you were as clever in conversation as you seemed in print. Nor does it seem as long as seven years since we actually met, and I learnt to value your cheerful, charming and provocative companionship. You deserve your honour, my dear friend, not only for your scientific work but for these human qualities which we have all appreciated on those few occasions when we have been able to have you with us in person.

Now that you have risen to this august rank you will, of course, have heavier administrative responsibilities-but you will also be able to play a larger part in the general direction of science in your country. Knowing you as I do, I can only feel that this will be beneficial both to the Soviet Union and to our subject throughout the world. The combination, within your person, of intellectual power and human judgment fits you almost uniquely for such a role.

Perhaps, therefore, you will excuse me, even on this especially happy occasion, if I mention something that has been worrying me from time to time and that has cast some small shadows over our friendship. It is not a matter that should stand between us personally -but I hope that you may exert your new-found authority to do something about it.

I allude to the extraordinary deficiencies, amounting sometimes to downright discourtesy, that hinder written communications and practical arrangements between Soviet scientists and ourselves. You must, I am sure, know the sort of thing I mean.

For example, a mutual friend arranged a conference here last December. Knowing the problems of "getting any Russians", he set to work in good time-or so he thought. In January he wrote to his opposite number in Moscow, an Academician, inviting him to come as a guest speaker. He also asked for the names of other good Russian scientists as possible invited speakers and participants. To this letter he received no answer. At the end of March, having nearly finalized the programme of review lectures, he wrote again to the Academician. Still no answer.

At this stage, he would have bcen justified in dropping all Russian names from the programme. However, being experienced in such business and genuinely wishing to hear at first hand about the work of the Moscow Institute, he wrote directly to the Presidium of the Academy and to the Ministry of Education, officially inviting six leading Russian scholars by name. This letter, sent in May, was answered in October, as follows "Dear Professor X, the Soviet delegation to your conference will consist of $\mathrm{Y}$ and $\mathrm{Z}$. Please make arrangements for them to receive visas to enter your country."

Unfortunately, the two names mentioned in this brief and uncivil communication were not among those asked for. Indeed they were practically unknown to our friend, who could only assume that they were junior workers who had not yet risen to international prominence. He wrote back asking for more information, pointing out that he would not now be able to include these names in the official programme as invited speakers, but would welcome them nevertheless. He also set in motion the Foreign Office machinery for granting visas.

Again nothing seemed to happen until three days before the start of the conference, when a cable (in Russian) demanded accommodation for eight Russian scientists, including now the Academician himself. With tremendous energy, the organizing secretary wheedled six more rooms out of the local hotels, aroused the Foreign Office to action, and rearranged the programme. He even set graduate students awaiting at the airport to guide the party. But nobody came.

Finally, in the last two days of the meeting three Russians appeared, unannounced. One of therm did not seem very familiar with the actual subject, but they all insisted on reading out their unscheduled communications. In the end, beer and rodka in the local pub resolved many inhibitions, and we soon became good friends. They were, indeed, full of apologies for any slight difficulty that may have been caused by the inefficiency of their bureaucracy-and once again we forgave them because, poor souls, it was not their fault that we had been put to so much trouble.

What puzzles me about such buffoonery (believe me, I do not exaggerate the sort of thing that often happens) is that it benefits nobody. If attendance at scientific conferences is valuable, then surely the most suitable Russian participants should have been chosen, by experts such as the Academician, and efficient arrangements made for their travel. Much expense and effort seems to have been wasted. And the international standing of Soviet science was not enhanced.

Well, of course, we too have our difficulties sometimes in persuading financial committees to make grants for travel to conferences, and in rearranging our university duties so as to get leave of absence: sometimes even nine months is an insufficient gestation period for such important administrative decisions. But at least the advice of expert scientists is followed. I know that it would not be fair to blame your Academician personally for this particular fiasco; but $\mathrm{I}$ cannot 
think of anyone else with the knowledge needed to take such decisions and to bear the responsibility for their success.

You must yourself have suffered through similar events, and do not need to be told by me that they are harmful to the Soviet Union and its scientific development. I can only say, as an outsider, that they really cause us a great deal of trouble, to the extent that many of us, in organizing international scientific meetings, may begin to feel that it is not worth the effort to try to get Russian participation. There is a limit, in terms of time and worry, to the price that we are prepared to pay for this commodity, however valuable it may be to us. I hope therefore that, in your new rank, you will press, through the Academy and other organs of the Soviet scientific community, for a great improvement in the practical management of all such matters.

Yet there is a more subtle aspect of relations between Russian and "western" scientists that cannot be improved by mere administrative reorganization. I have mentioned letters that were not answered, nay, not even acknowledged. Friends have told me of the rebuffs they have received in planning a visit to the Soviet Union. For example, polite requests to talk to such and such a scientist have been fobbed off or simply ignored. We all know of the custom of translating scholarly works into Russian, without consulting the author, despite the advantages that may be gained from his advice concerning printing errors. Are these and other incivilities always to be forgiven ?

Can it be that you and your colleagues are simply unfamiliar with our ways, just as we must be with yours? Consider, for example, the general tone in which correspondence is conducted between established scientists in different countries. It is hard to characterize this tone specifically, but it is always courteous and friendly, whether formal or informal. From an unknown German or Italian, a letter might be written in the old-fashioned style of conventional respect; from an American friend it might be all on first-name terms, with chat about each other's family. In every case, the letter would be addressed as from person to person, without passing through the bureaux of organizations, academies, universities, or other institutions. The courtesies would be those normal between independent individuals, asking perhaps for advice or assistance, regretting in return the inability to give such help, conveying opinions or information, making practical arrangements, etc.

The point is that, however much we may be in fact employees of universities, government laboratories or industrial corporations, we still like to regard ourselves as persons of independent standing, capable of deciding for ourselves on all matters associated with our professional activities-what subjects to work on, when and what to publish, whom to meet and talk to, where to go for conferences and advanced instruction. I do not say that we are in fact quite as free as we like in all such questions; we must, indeed, perform our university duties and otherwise satisfy our directors of research and governing boards-but we are not mere functionaries. To fail to answer a letter from one such scholar to another is therefore something worse than administrative inefficiency-it is a personal insult. To act as if one scientist is interchangeable with another as the speaker in a conference is an attack on the personal standing of each one of us. To give meaning to our work, we need to preserve the illusion that we are contributing individually to the growth of knowledge and that each one of us deserves to be treated as the independent proprietor and cultivator of his own little cabbage patch in the land of learning.

You yourself, I know, have never offended in this way; all I ask now is that you try to explain to your colleagues the importance of such apparently small issues. Our mutual good relations depend on an implicit respect for each other's position by an explicit regard for his social conventions. An improvement at this level would be of far greater benefit than any number of cultural exchange agreements between our respective governments.

These benefits would not be merely a vague increase in "international understanding". It is now clearly established, by those who have studied the sociology of science, that the informal channels of communication between scholars are quite as important as the official organs of scientific publication. Information about new discoveries and new techniques diffuses very rapidly through our scholarly communities by means of letters, visits and personal contacts at conferences. To be cut off from such contacts is one of the main complaints of scientists in small countries, far from Europe and North America; it hampers their research at every level, seeming to make it always a little out of date. If we could unblock these channels between the Soviet scientific community and our own, then we should both benefit greatly; we should not have to learn, by painful experience, some of the things that you already know; your research would always start from the best possible basis of knowledge, including some of those subtle ideas that we have already conceived. I cannot emphasize this point too strongly to you, to your professional Russian colleagues, and to all those who have anything to do with the scientific development of your country. I know very well that there are obstacles to the opening of all doors between your scholarly community and our own; at least a general amelioration of the level of civility in personal communications would unlatch a few windows between us.

You will, I trust, forgive me for having spoken so bluntly. I have not the least complaint against the way that you have treated me over these many years. The role of the "candid friend" is dangerous and foolish in personal relations. But this is not, in the end, a question of the relationship between private individuals; it concerns whole communities, great nations and our common dedication to the pursuit of knowledge; to fail to speak our minds honestly is to betray our social responsibilities. Perhaps we too are unwittingly offending you by our behaviour; give us the opportunity to show our emotional maturity by accepting your criticism in a humble spirit.

Meanwhile, dear friend, we must make the best of our little lives within our chosen spheres. Once more let me congratulate you on the recognition that has crowned those past years of toil and effort and wish you many years of further success, the delights of yet more discoveries, and the fruits of wisdom and understanding.

Arrivederci: to the time when we meet again. Yours ever,

H. H. Wills Physies Laboratory, John Ziman University of Bristol. 